\title{
UPACARA SEBA PADA MASYARAKAT BADUY
}

\author{
Seba Ceremony in Baduy Society
}

\author{
Oleh Endang Supriatna \\ Balai Pelestarian Nilai Budaya Bandung \\ Jln. Cinambo No. 136 Ujungberung Bandung \\ Email: supri1159@yahoo.com
}

\begin{abstract}
Abstrak
Desa Kanekes adalah salah satu desa di Kecamatan Leuwidamar Kabupaten Lebak Propinsi Banten. Sebagian besar tanahnya merupakan dataran tinggi yang bergunung dengan lembah-lembah yang merupakan daerah aliran sungai dan hulu-hulu sungai yang mengalir ke sebelah utara. Bagian tengah dan selatan desa merupakan hutan lindung atau hutan tutupan yang oleh penduduknya, yaitu Orang Baduy, sangat dijaga kelestariannya. Seba merupakan sebuah tradisi yang setiap tahun dilaksanakan oleh masyarakat Baduy sebagai wujud nyata tanda kesetiaan dan ketaatan kepada penguasa. Seba itu sendiri merupakan peristiwa dalam untaian adat masyarakat Baduy yang dilakukan seusai upacara Kawalu dan Ngalaksa. Upacara Seba mereka laksanakan melalui persiapan yang matang serta berpedoman pada peraturan adat. Orang yang berperan melakukan Seba adalah kepercayaan Puun atas nama warganya untuk memberikan laporan kepada Pemerintah sekaligus menjembatani komunikasi. Tulisan ini menggunakan metode deskriptif, yaitu mendeskripsikan secara rinci fenomena sosial tertentu. Sedangkan pendekatan yang digunakan adalah pendekatan kualitatif. Yaitu pendekatan yang menggambarkan persoalan manusia dan kebudayaannya yang kompleks dan menyeluruh.
\end{abstract}

Kata Kunci: Masyarakat Baduy, Nilai Budaya, Upacara Seba

\section{Abstract}

Seba (giving tribute) ceremony is performed every year by the Baduy of Desa (village) Kanekes, district of Leuwidamar, regency of Lebak, the Province of Banten. It is a manifestation of signs of loyalty and obedience to the ruler. It is a part of a series of customary ceremony that is carried out by the Baduy after Kawalu and Ngalaksa ceremonies. Puun (the chief) gives authority to a member of his community to perform seba to deliver report to government and to bridge communication between them. This is a descriptive-qualitative research. It is hoped that the author could describe a more detailed information concerning certain social phenomenon such as seba.

Keywords: Baduy society, cultural values, seba ceremony 


\section{A. PENDAHULUAN}

Berbicara tentang masyarakat dan kebudayaan secara umum, para ahli berbeda pendapat terutama tentang arti masyarakat, karena masyarakat itu sesuatu yang "hanya ada dalam gambaran saja sehingga tidak dapat ditentukan dengan menentukan waktu dan tempatnya" (Shadily, 1990: 31). Sebaliknya M.J. Herskovits berpendapat "bahwa masyarakat adalah kelompok individu yang diorganisasikan yang mengikuti satu cara hidup tertentu" (Harsojo, 1982: 144). Pendapat lain yang cukup rumit adalah arti masyarakat yang dikemukakan Polak (1976: 13). Ia menyimpulkan bahwa masyarakat adalah wadah antar hubungan antara kolektivitas dan kelompok yang tersusun secara hirarkhis, sejajar dan setaraf atau saling tembus menembus. Di samping itu, masih banyak lagi pendapat lain tentang hal ini. Dari berbagai pendapat para ahli itu, pendapat Herskovits yang dikutip Harsojo tampaknya lebih tepat.

Sedangkan pengertian kebudayaan menurut Harsojo yang mengutip pendapat E.B. Tylor (Harsojo, 1982: 109), "adalah keseluruhan yang kompleks, yang di dalamnya terkandung ilmu pengetahuan, kepercayaan, kesenian, moral, hukum, adat istiadat dan kemampuan yang lain serta kebiasaan yang didapat oleh manusia sebagai anggota masyarakat." Pendapat yang hampir seirama dengan itu adalah seperti yang dikemukakan oleh Parsudi Suparlan (Suparlan, 1981: 78), yaitu "Keseluruhan pengetahuan manusia sebagai mahluk sosial, yang digunakan untuk menginterpretasi dan memahami lingkungan yang dihadapi dan untuk menciptakan serta mendorong terwujudnya kelakuan." Dengan ungkapan lain, kebudayaan mencakup semua hal yang didapatkan atau dipelajari manusia, baik dalam cara berpikir dan merasakan maupun dalam bertindak. Pengertian yang lebih umum dalam sosiologi, kebudayaan adalah hasil cipta, rasa, dan karsa manusia.

Terlepas dari berbagai pengertian itu yang menurut Harsojo tidak kurang dari
160 definisi kebudayaan (1982: 109), namun yang jelas antara masyarakat dan kebudayaan terdapat kaitan yang erat sekali. Demikian pula keterkaitan antara masyarakat Kanekes dan kebudayaannya, antara lain keterikatan mereka dengan aspek kepercayaan, moral hukum, adat istiadat, dan sebagainya.

Keanekaragaman budaya, yang berkaitan dengan religi khususnya dalam bentuk upacara-upacara yang ada pada masyarakat Indonesia sangat banyak dan menarik untuk diamati dan diteliti, karena di dalamnya terkandung makna dan nilainilai berharga yang disampaikan secara khas dan unik lewat simbol-simbol yang diciptakan oleh masyarakat itu sendiri. Salah satu bentuk dari religi dan upacara tersebut adalah kegiatan "Upacara Seba" yang menjadi tradisi masyarakat Baduy. Upacara Seba ini adalah suatu upacara adat yang dilaksanakan untuk kegiatan ritual tahunan warga Baduy dimaksudkan sebagai bentuk rasa syukur untuk menjalin silaturahmi kepada pemerintah Kabupaten Lebak dan Provinsi Banten, setelah warga Baduy di Banten Selatan tersebut melaksanakan panen hasil pertanian. Sebelum melaksanakan Upacara Seba kepada pemerintahan Provinsi Banten, warga Baduy Luar dan Baduy Dalam, juga melaksanakan kegiatan serupa di kantor Bupati Lebak.

Pada Upacara Seba ini sarat dengan makna atau nilai-nilai budaya, Makna dari semua nilai budaya yang ada dalam Upacara Seba ini mengandung petuah, nasehat, dan amanah kepada pemimpin, agar kiranya bisa menempatkan diri sebagai pemimpin yang menjadi pola anutan rakyatnya (amanah), tidak sewenang-wenang dalam bertindak walaupun seorang pemimpin memiliki kekuasaan yang sangat luas. sehingga amanah seorang pimpinan kepada warganya, harus diikuti dan didukung oleh masyarakat, khususnya warga Baduy setempat. Upacara ini juga menjadi bukti adanya pengakuan secara adat kepada pejabat bupati dan gubernur bahwa secara 
informal mereka menjadi pemimpin masyarakat Baduy.

Biasanya untuk pelaksanaan upacara dipilih waktu yang terbaik yaitu hari dan tanggal pelaksanaannya yang baik, terutama setelah selesai panen. Sedangkan tempat pelaksanaan upacara di Rangkasbitung tepatnya pendopo Kabupaten Lebak atau pendopo Ibukota Propinsi di kota Serang. Perayaan Seba tersebut dilaksanakan di Pendopo Kabupaten Lebak dan dihadiri Kepala Daerah dan pejabat Muspida setempat. Perayaan upacara Seba Baduy merupakan tradisi dari peninggalan nenek moyang yang bertujuan menjalin silatuhrahim dengan "Bapak Gede" (kepala pemerintah).

Tujuan penelitian ini pada dasarnya adalah untuk menggali pemahaman tentang upacara adat Seba yang masih berlaku pada masyarakat Baduy, tahapan upacara, pelaksanaannya, serta nilai-nilai yang terkandung dari upacara adat tersebut. Hasilnya, diharapkan dapat dijadikan sebagai masukan dalam pengambilan kebijakan bagi kelestarian masyarakat itu sendiri.

Ruang lingkup penelitian ini meliputi dua hal, yakni lingkup wilayah dan lingkup materi. Wilayah penelitian ini adalah Desa Kanekes Kecawatan Leuwi Damar Kabupaten Lebak Provinsi Banten yang merupakan tempat menetap komunitas masyarakat Baduy.

Adapun materinya tentang upacara Seba yang setiap tahun selalu dilaksanakan oleh masyarakat Kanekes. Pelaksanaan upacara Seba merupakan rangkaian dari upacara yang mendahuluinya, yaitu upacara Kawalu dan Ngalaksa. Simbol dan makna upacara, serta nilai-nilai yang terkandung dalam upacara Seba.

Metode penelitiannya adalah deskriptif yaitu mendeskripsikan secara rinci untuk fenomena sosial tertentu. Pendekatan yang digunakan adalah kualitatif. Pendekatan ini digunakan untuk memahami persoalan manusia dan kebudayaan, berdasarkan kepada gambaran yang kompleks dan menyeluruh.

\section{B. HASIL DAN BAHASAN}

Masyarakat Baduy biasa disebut juga "masyarakat Kanekes" atau "masyarakat Rawayan" adalah suatu kelompok masyarakat Sunda yang kehidupannya sangat tradisional. Mereka tinggal di daerah-daerah bukit terpencil, di daerah hutan wilayah pedesaan Banten Selatan.

Pada dasarnya mereka menyebut dirinya sebsagai masyarakat Desa Kanekes. Adapun sebutan Baduy, adalah sebutan dari masyarakat luar yang diberikan kepada mereka (masyakat Kanekes). Sedangkan mereka sendiri sebetulnya tidak menyukai sebutan Baduy, namun nama ini sudah sedemikian meluas; sehingga mereka sudah tidak bisa menolak sebutan ini. Merek menyebut dirinya sebagai orang Rawayan, atau orang Kanekes. Sebutan sebagai orang Kanekes disebabkan kerena memang mereka tinggal di wilayah yang disebut Desa Kanekes. Ada beberapa pendapat tentang asal muasal sebutan Baduy yang terdapat dalam beberapa sumber, yaitu sebagai berikut:

Istilah Baduy diambil dari nama tempat yang diambil dari nama sungai Cibaduy. Dari nama sungai Cibaduy ini kemudian menyebut nama orang-orang yang tingga di wilayah sekitar itu sebagai orang Baduy. Istilah Baduy disebutkan pula menunjuk pada pohon yang tumbuh di wilayah kampung mereka dan tidak tedapat di kampung lainnya. Pohon itu bernama Baduyut, maka istilah Baduy pun diabadikan untuk memberi nama masyarakat yang tinggal di tempat pohon itu tumbuh. Keterangan lain menyebutkan bahwa kata Baduy berasal dari kata Budha, yaitu agama yang dianut oleh Prabu Siliwangi dan rakyat kerajaan Pajajaran. Dari kata Budha lama-lama berubah menjadi Baduy dan dijadikan nama masyarakat keturunan Prabu Siliwangi yang masih tinggal di kampung itu. Terdapat pula keterangan yang menyebutkan bahwa islitah Baduy diambil dari kata Bahasa Arab: Badui, yang menunjuk pada masyarakat Arab (yang dimaksud yaitu negara Arab Saudi) yang 
tinggal di pinggiran kota dan masih terbelakang dari segi ekonomi, politik, dan sosial. Istilah Badui beradaptasi dengan lidah orang Sunda menjadi kata Baduy. Dari kata ini pula muncul sebutan untuk menamakan masyarakat terisolir dan terbelakang seperti halnya terhadap masyarakat Desa Kanekes.

Terdapat tiga versi/pendapat yang menerangkan asal usul mereka:

Pertama, pendapat yang menyatakan bahwa pada awalnya masyarakat Baduy merupakan kelompok masyarakat yang berasal dari para Punggawa Kerajaan Pajajaran (sekitar abad XVI) yang melarikan diri dari kerajaan, karena masuknya agama Islam ke wilayah Banten melalui Pantai utara Cirebon. Mereka melarikan diri ke wilayah Banten Selatan, di wilayah pegunungan Kendeng. Masyarakat pelarian tersebut menganut agama Hindu yang semula menetap di daerah Tanah Sareal Bogor (Jacobs \& Meijer, 1891; Darmawijdjaja, 1968; Edi S. Ekadjati, 1995 dalam Suhada, 2003: 47).

Kedua, pendapat yang menyatakan bahwa mereka (seperti yang terdapat dalam data kepurbakalaan Banten) berasal dari kelom-pok masyarakat pengungsi yang terdesak oleh gerakan perluasan wilayah kekuasaan dan peng-Islaman dari Kesultanan Banten. Mereka menganut agama Hindu, dan pada amulanaya menetap di sekitar Gunung Pulosari (Kabupaten Pandeglang) yaang berhasil ditundukkan oleh Kesultanan Banten dan para serdadunya. Sebagian diantaranya berhasil melarikan diri ke arah selatan dan membuka pemukiman baru di tempat pengungsian mereka. Maka jadilah daerah pemukiman masyarakat Baduy (Kooders, 1864; Pennings, 1902; Tricht, 1929; Edi S. Ekadjati, 1995; dalam Suhada, 2003: 47).

Ketiga, berdasaarkan pengakuan masyarakat Baduy itu sendiri. Menurut mereka, sejak dahulu leluhur mereka tinggal dan hidup di daerah yang mereka tempati sekarang, yaitu Desa Kanekes. Mereka menolak pendapat yang menyatakan bahwa masyarakat Baduy merupakan masyarakat pengungsi/pelarian dari Pakuan Pajajaran. Dengan bernada kesal, beberapa diantara mereka menyatakan bahwa sejak jaman dahulu, mereka telah bermukim di daerah Kanekes (Suhada, 2003: 48).

Wilayah Kanekes itu berdasarkan lokasi geografisnya terletak kira-kira pada $6^{\circ} 27^{\prime} 27^{\prime \prime}-6^{\circ} 30^{\prime}$ Lintang Utara (LU) dan $108^{\circ}$ 3' 9" - $106^{\circ}$ 4' 55" Bujur timur (BT) (Permana, 2001). Wilayah yang ditempati masyarakat Baduy merupakan bagian dari Pegunungan Kendeng, dengan kondisi wilayah tersebut merupakan daerah yang bertopografi berbukit dan bergelombang dengan kemiringan tanah rata-rata mencapai $45^{\circ}$. Sistem pertaniannya dengan sawah kering, yakni menanam padi dengan sistem huma bukan sawah tadah hujan atau model sawah pada masyarakat Jawa dan Sunda pada umumnya. Wilayah yang tersusun oleh perbukitan yang sambung menyambung, biasanya masyarakat Baduy bermukim tepat di kaki pegunungan Kendeng di desa Kanekes, dengan ketinggian $300-600 \mathrm{~m}$ di atas permukaan laut (DPL). Struktur tanahnya merupakan tanah vulkanik (di bagian utara), tanah endapan (di bagian tengah), dan tanah campuran (di bagian selatan), dengan suhu rata-rata 20 ${ }^{\circ} \mathrm{C}$. Dengan kondisi demikian wilayah yang menjadi tempat tinggal masyarakat Baduy merupakan tanah yang subur. Tiga desa utama orang Kanekes Dalam adalah Cikeusik, Cikertawana, dan Cibeo, yang terdiri dari banyak perkampungan orang Baduy yang tersebar di wilayah pegunungan Kendeng.

Bahasa yang dipergunakan oleh penduduk Desa Kanekes atau orang Baduy, adalah bahasa Sunda dialek Baduy. Bahasa Sunda Baduy menurut sebagian pendapat merupakan bahasa asli orang Sunda (Suhandi, 1986: 33), sebab bahasa yang dipergunakan mereka ini menunjukkan ciri-ciri demokratis dan tidak mengenal tingkatan bahasa (undak usuk bahasa) yang biasanya merupakan pulasan, karena berdasarkan status sosial. Harsojo dalam tulisannya yang berjudul Kebudayaan 
Sunda (Koentjaraningrat, 1975: 300), menyebutkan bahwa bahasa orang Baduy adalah bahasa Sunda Kuno.

Konsep penting bagi orang Kanekes berkaitan dengan nilai budaya mereka adalah Pikukuh. Mereka menyebut pikukuh dengan istilah buyut, yaitu sesuatu yang tidak boleh dilanggar. Buyut dalam pengertian ini, dapat dikatakan dengan istilah tabu bagi masyarakat lainnya. Pengertian pikukuh bagi masyarakat Kanekes dapat diartikan sebagai peraturan, hukum adat, atau patikrama yang tidak boleh dilanggar. Dalam pengertian seperti disebut di atas

Dalam bahasa Sunda yang umum kata buyut sebagai arti terlarang atau tabu tidak dikenal; karena dalam bahasa Sunda secara umum (selain orang Kanekes) buyut merupakan sebutan kepada generasi ketiga ke atas setelah ego (artinya: ego, kolot/orang tua, embah/ kakek-nenek, dan buyut/ ayah atau ibu dari kakek-nenek). Selain itu, dalam bahasa Sunda yang umum perkataan buyut merupakan sebutan atau panggilan generasi ketiga di bawahnya setelah ego (ego, anak, incu/ cucu, dan buyut). Kalau buyut dalam dialek Kanekes yang menunjuk pada arti kata tabu/larangan, dalam bahasa Sunda yang umum disebut cadu atau pamali.

Pengertian buyut, bagi orang yang beragama Islam, mungkin dapat diartikan sebagai haram yaitu perkara yang tidak boleh dilakukan menurut pandangan agama Islam. Dan bagi orang Kanekes pikukuh ini memang berkaitan erat dengan agama atau kepercayaan mereka yang dinamakan agama Sunda Wiwitan.

Mengutip A. Suhandi Shm. dkk., dalam bukunya (A. Suhamdi Shm. dkk., 1986: 47-48) menyebutkan konsep pikukuh berupa kalimat-kalimat yang sudah baku. Kalimat-kalimat yang berupa pikukuh tersebut adalah sebagai berikut (pada bagian sebelah kana merupakan terjemahan dalam bahasas Indonesia):

Buyut nu
$\begin{aligned} & \text { dititipkeun ka } \\ & \text { Puun }\end{aligned}$

Nagara satelung puluh telu

Bagawan sawidak lima

Pancer salawe nagara

Gunung teu meunang dilebur Lebak teu meunang diruksak

Larangan teu meunang dirempak Buyut teu meunang di robah Lojor teu meunang dipotong Pondok teu meunang disambung $\mathrm{Nu}$ lain kudu dilainkeun $\mathrm{Nu}$ ulah kudu diulahkeun

$\mathrm{Nu}$ enya kudu dienyakeun

Mipit kudu amit

Ngala kudu menta

Ngeduk cikur kudi mihatur

Nyokel jahe kudu micarek

Ngagedag kudu bewara

Nyaur kudu diukur

Nyabda kudu diunggang

Ulah ngomong sageto-geto Ulah lemek sadaek-daek
- Nagara tiga luluh tiga

- Begawan (Resi, pendeta) 65

- Pusatnya (maksudnya pusat dunia) dua puluh lima negara

- Gunung tidak boleh dilebur

- Lembah tidak boleh dirusak

- Larangan tidak boleh dilanggar

- Pantangan (adat) tidak boleh diubah

- Panjang tidak boleh dipotong

- Pendek tidak boleh disambung

- Yang bukan harus dianggap bukan

- Yang terlarang ( oleh adat) harus dianggap terlarang

- Yang benar harus dinyatakan benar (jangan dipalsukan)

- Mengambil (milik orang) harus minta izin

- Memetik/mengambil harus meminta

- Mengambil kencur harus memberitahukan pemiliknya

- Mencungkil jahe harus memberitahukan

- Mengguncang (pohon buah supaya buahnya jatuh) harus memberitahukan dahulu

- Berkata (mengeluarkan ucapan ) harus dipikir dahulu

- Berkata (mengeluarkan perintah) harus dipikir agar tidak menyakitkan

- Jangan berbicara sembarangan

- Jangan berbicara seenaknya 


$\begin{array}{ll}\begin{array}{l}\text { Ulah maling } \\ \text { papanjingan }\end{array} & \begin{array}{c}\text { - Jangan mencuri meski } \\ \text { dalam kekurangan }\end{array} \\ \begin{array}{l}\text { Ulah jinah } \\ \text { papacangan }\end{array} & \begin{array}{l}\text { - Jangan berzina dan } \\ \text { berpacaran }\end{array} \\ \begin{array}{l}\text { Kudu ngadek } \\ \text { sacekna }\end{array} & \begin{array}{c}\text { - Kalau nemotong (dengan } \\ \text { benda tajam) harus tepat } \\ \text { dan sekali tebas }\end{array} \\ \begin{array}{l}\text { Nilas saplasna } \\ \text { Akibatna }\end{array} & \begin{array}{l}\text { - Menebas setepatnya } \\ \text { - Akibatnya (kalau semua } \\ \text { buyut dilanggar) }\end{array} \\ \begin{array}{l}\text { Matak urung jadi } \\ \text { ratu }\end{array} & \text { - Bisa gagal jadi pemimpin } \\ \begin{array}{l}\text { Matak edan jadi } \\ \text { menak }\end{array} & \text { - Menjadi menak } \\ \begin{array}{l}\text { Matak pupul } \\ \text { pangaruh } \\ \text { Matak hambar }\end{array} & \text { - Bisa hilang pengaruh } \\ \text { komara } & \text { - Bisa hilang wibawa } \\ \begin{array}{l}\text { Matak teu mahi } \\ \text { juritan } \\ \text { Matak teu jaya } \\ \text { perang }\end{array} & \text { - Bisa kalah dalam } \\ \begin{array}{l}\text { Matak eleh } \\ \text { jajaten }\end{array} & \text { - Bertempur } \\ \begin{array}{l}\text { Matak eleh } \\ \text { kasakten }\end{array} & \text { - Bisa hilang pereng } \\ \end{array}$

Pikukuh yang disebutkan di atas, dalam anggapan masyarakat Kanekes merupakan amanat karuhun (leluhur) yang dititipkan kepada Puun agar dipelihara sebagai ketentuan adat yang tidak boleh dilanggar. Dan jika diperhatikan dengan seksama, sesungguhnya dalam Pikukuh itu tersirat konsep ketakwaan terhadap Tuhan Yang Maha Esa, meskipun dalam kenyataan kepercayaan itu tidak begitu jelas bentuknya. Kemudian dalam kaitan dengan peranan dan penampilan Puun sebagai sosok pemimpin yang menjadi panutan warganya, harus mematuhi pula beberapa buyut khusus.

Beberapa buyut khusus yang harus dipantang oleh Puun, menurut A. Suhandi Shm. (1986: 48) ialah:

- Tidak boleh beristri lebih dari seorang

- Tidak boleh makan daging

- Kalau menjadi Puun dalam usia muda, tidak boleh bertemu dengan orang luar sebelum mencapai usia (umur) 25 tahun
- Makan harus menggunakan piring kayu, cangkir awi (bambu) atau batok (tempurung) kelapa

- Tidak boleh merokok

- Tidak boleh bepergian ke luar kecuali dipanggil Bupati/ Pemerintah. Itupun tidak boleh menggunakan kendaraan

Dengan demikian keteladanan dari pemimpin di kalangan masyarakat Kanekes penting sekali. Itulah sebabnya, maka orang-orang Panamping (Baduy Luar) dan Dangka (di luar Desa Kanekes) begitu takut dan tidak bisa berkutik, apabila para pengawas adat dari Tangtu (Baduy Kajeroan) datang mengadakan semacam operasi bersih, menyidik dan memasuki rumah-rumah masyarakat Panamping untuk memeriksa perabotan rumah tangga yang tidak diperbolehkan dalam Pikukuh.

Keyakinan, atau agama masyarakat Kanekes yang disebut Sunda Wiwitan, memiliki keyakinan hidup yang mengharuskan mereka menerima saja nasib yang telah ditentukan (hirup narimakeun). Keyakinan itu pula yang menyebabkan mereka selalu hidup sederhana.

Masyarakat Baduy menganggap tanah mereka, yaitu Desa Kanekes merupakan "bumi suci" (tanah kancana) yang kaya. Tanah ini juga dianggap sebagai taneuh larangan, terlarang bagi orang lain namun suci bagi mereka. Karena itu tanah ini merupakan titipan yang harus dipelihara dan dijaga, terutama yang disebut sebagai tiang alam semesta, yaitu Sasaka Domas. Menurut keyakinan Masyarakat Kanekes, Dunia tempat hidup manusia ini ada tiga bagian, yaitu dunia atas, dunia tengah, dan dunia bawah. Tiaptiap bagian dari dunia itu ada yang mengurus atau penguasanya masingmasing.

Dunia bawah (dunia handap) atau bumi yang ditinggali ini dikuasai oleh 'penguasa bumi' (Ambu Handap) atau Ambu Rarang, dunia tengah oleh Ambu Tengah, dan dunia atas oleh Ambu Luhur 
yang bersemayam di "sorga" (Nagara Suci), yang disebut pula Buana Nyungcung, yakni dunia puncak. Menurut keyakinan mereka, seseorang yang hidup di dunia ini bernaung kepada Ambu Tengah; tetapi jika mati dimasukkan ke Ambu Handap (maksudnya dikuburkan). Setelah tujuh hari berada di dalam bumi (dalam kubur), ia akan naik ke dunia atas menghadap Ambu Luhur atau Buana Nyngcung, dan semua orang Kanekes (khususnya orang Tangtu atau Baduy Dalam) akan masuk Nagara Suci ('sorga'). Karena itu orang Baduy tidak pernah merawat kuburan, kecuali hanya selama tujuh hari itu saja.

Aspek lain yang juga menarik dari ajaran agama ini adalah bahwa terciptanya dunia dimulai dari Desa Kanekes, yang mula-mula sagede siki pedes (sebesar biji merica) lalu berkembang menjadi dunia yang dikenal sekarang. Setelah dunia menjadi besar dengan pancer (pusat di Kanekes, penguasa dunia atas (Ambu Luhur) menciptakan Batara Tujuh, yang merupakan cikal bakal manusia yang mengurus dunia. Di "pusat" dunia itu (Kanekes) kampung yang pertama diciptakan adalah Cikeusik, kemudian Cikertawana. Kedua kampung ini dititipkan kepada salah satu dari Batara Tujuh yang disebut "Daleum". Setelah itu barulah Cibeo diciptakan, yang dititipkan kepada salah satu dari Batara Tujuh juga yang disebut "Menak" . Keturunan dari "Daleum" dan "Menak" ini kemudian bernama Puhu (Puncak) dan lambat laun berubah sebutan menjadi Puun, ketua adat Baduy.

Ibadah dalam Agama Sunda Wiwitan ini tidak jelas ketentuannya. Di pusat kekuasaan Baduy yaitu tiga kampung Tangtu (Cikeusik, Cikertawana, dan Cibeo) tidak dijumpai sebuah tempat ibadah pun. Bagi mereka segala bentuk perbuatan baik dianggap ibadah, dan semua bentuk perbuatan yang tidak baik harus dijauhi atau buyut (tabu) untuk dilakukan.
Cara yang ditempuh untuk menjauhi dan menghindarkan perbuatan atau perilaku yang tidak baik itu, mereka bersikap "tidak kuasa atau tidak berani" (teu wasa). Karena itu, mereka sangat teguh berpegang kepada pikukuh, meskipun tidak tertulis, namun secara konvensional dimengerti oleh semua orang Baduy. Setiap orang Baduy melakukan pelanggaran terhadap pikukuh akan dikenakan hukuman; mengenai berat atau tidaknya hukuman itu sangat tergantung kepada jenis pelanggarannya. Berbeda jika orang luar yang melanggar buyut, mereka tidak dapat melaksanakan hukuman, namun mereka tetap yakin bahwa si pelanggar pada akhirnya akan menerima akibatnya juga.

Dengan demikian, menurut kepercayaan mereka dalam menempuh kehidupan di dunia nyata ini pedomannya adalah pertabuan (buyut) yang telah melekat dalam tradisi, berupa tabu yang berasal dari para leluhur (buyut karuhun), tabu para wali (buyut para wali) tabu para nabi (buyut para nabi), tabu yang berhubungan dengan tanaman (buyut karang), dan lainlain. Batas waktu berlakunya buyut tidak sama antara satu dengan yang lain. Misalnya buyut karuhun tidak berlaku lagi setelah 750 tahun. Di antara tabu yang berhubungan dengan tanaman (buyut karang) adalah tabu menanam cengkeh, kopi, karet, bersawah, membajak, menggunakan pupuk buatan (pabrik), dan tabu mengambil hasil hutan dari lingkungan hutan suci (leuweung larangan).

Corak hubungan dan kegiatan religius orang Kanekes yang berkenaan dengan dunia gaib dalam konteks kepercayaan Agama Sunda Wiwitan, termanifestasikan dalam berbagai aktivitas kehidupan sehari-hari. Aktivitas ini tidak dapat dipisahkan dengan penyelenggaraan upacara, walaupun tidak semua upacara berhubungan dengan dunia gaib. Karena di antara upacara itu erat kaitannya usaha pertanian, siklus kehidupan individu, perhitungan hari baik dalam melakukan 
pekerjaan penting, atau berkaitan dengan penentuan jodoh, dan sebagainya.

Menurut Garna (dalam Kuntjaraningrat, 1993: 66), jalinan antara ketentuan adat dengan agama sedemikian eratnya sehingga dapat dianggap bahwa adat merupakan bagian tak terpisahkan dari agama. Dengan perkataan lain, agama terisi berbagai ketentuan adat yang harus ditaati oleh setiap orang Baduy sebagai pedoman dalam kehidupan mereka. Dan kepercayaan yang kuat terhadap semua ketentuan yang ditetapkan puun merupakan manifestasi dari ketaatan mereka kepada amanat para leluhur.

Menurut kepercayaan dalam agama Sunda Wiwitan, para Batara Tujuh, Daleum dan Menak yang menjadi nenek moyang mereka tidak pernah mati, hanya roh dan jasadnya saja yang ngahiyang (menghilang). Karena itu, mereka yakin Kanekes tidak akan hilang selama masih dipelihara oleh keturunan para Batara, yaitu Puun dan orang Baduy pada umumnya.

Orang Baduy, harus berperilaku baik dan bersamadi (tapa) menyatukan diri dengan Batara Tunggal selama mereka hidup. Batara Tunggal bagi orang Baduy adalah Gusti Nu Ngersakeun (Tuhan Yang maha Kuasa), tetapi ia dianggap sebagai manusia biasa yang tidak mati, hanya ngahiyang (raib) dengan jasadnya dari dunia ini. Menurut alam pikiran orang Baduy, kehidupan manusia dan nasibnya diatur oleh suatu kekuatan gaib yang tidak tampak oleh pandangan manusia, yakni kekuatan Batara Tunggal yang raib itu. Falsafah hidup dalam kepercayaan agama ini tidak mementingkan keduniawian, tetapi lebih mementingkan kerohanian. Dari sikap inilah terlihat kondisi hidup mereka yang sederhana, narimakeun (menerima apa adanya menurut ketentuan yang sudah ditetapkan); dan dengan hidup sederhana itulah mereka mencapai kepuasan.

Berkaitan dengan kepercayaan kepada Tuhan Yang Maha Esa, Nu Ngersakeun; mereka menganggap ada di suatu tempat suci yang menjadi tempat bersemayamnya sang Batara Tunggal. Itulah lokasi yang kini terdapat Arca Domas atau Sasaka Para Pusaka; di mana konon pada jaman baheula (masa dahulu kala) sang Batara dan roh para leluhur (para Sanghiyang) berkumpul. Lokasi Arca Domas, karena dianggap tempat yang paling Suci selalu dirahasiakan, bahkan orang Baduy Tangtu sendiri pun banyak yang tidak mengetahuinya. Diperkirakan, tempat itu terletak di hulu sungai Ciujung dan Cisimeut. Setiap tahun, tempat ini dibersihkan oleh sembilan orang yang dipimpin oleh Puun Cikeusik (Puun Rama). Para tokoh Baduy yang sembilan itu, antara lain Girang Seurat, Tangkesan, dan Baresaan, serta Jaro Tangtu. Pembersihan ini dilaksanakan selama dua hari pada setiap bulan Februari atau bulan Kalima menurut kalender Baduy. Selain itu, pembersihan juga dilakukan menjelang penyelenggaraan upacara pemujaan.

Dari uraian di atas, terutama tentang sikap dan falsafah hidup yang narimakeun (menerima ketentuan yang telah digariskan), dapat diasumsikan bahwa sikap hidup sederhana, menerima apa adanaya sesungguhnya merupakan bagian dari aspek ketakwaan kepada Tuhan Yang Kuasa. Dalam pelaksanaan upacara-upacara manifestasi keyakinan terhadap kepercayaan mereka, di antara upacara-upacara dimaksud adalah:

\section{Upacara Kelahiran dan Cukuran}

Sama seperti di pedesaan Sunda lainnya, kelahiran bayi ditolong oleh bidang kampung/dukun beranak yang disebut paraji atau indung beurang, demikian pula dengan masyarakat Kanekes. Begitu selesai menolong kelahiran itu, sang paraji biasanya akan memperoleh bingkisan dari keluarga yang melahirkan, berupa ayam, nasi tumpeng, dan beberapa makanan lainnya. Setelah 40 ha, si ibu harus mandi bersih (beberesih) dengan keramas atau diangir oleh paraji Pada waktu mandi inilah paraji memanterai air yang dicampur dengan aneka kembang serta kunyit (koneng) yang dipergunakan 
untuk diangir. Upacara mencukur rambut bayi (cukuran) juga dilakukan oleh paraji. Demikian pula dengan pemberian nama. Hanya saja khusus untuk pemberian nama -yang biasanya dilakukan pada hari ke tujuh - ada ketentuan spesifik yang berlaku di Kanekes. Menurut Danasasmita, suku kata pertama dari laki-laki harus sama dengan suku kata pertama dari nama ayahnya. Sedangkan untuk nama anak perempuan ketentuan itu dikaitkan dengan nama ibunya (Danasasmita, 1986: 65). Pasangan yang mendapat anak dianggap sebagai pertanda bahwa mereka dipercayai oleh Yang Kaha Kuasa.

\section{Upacara Sunatan}

Sunatan menurut sebagian sumber merupakan tradisi asli dari suku Sunda pada umumnya; demikian pula anggapan masyarakat Kanekes. Dalam kaitan ini, agak terasa ganjil adalah istilah yang mereka berikan kepada upacara sunatan, yaitu nyilamkeun atau ngeslamkeun (mengislamkan). Berarti setidaktidaknya upacara ini pun dianggap ada kaitannya dengan dunia gaib.

\section{Upacara Perkawinan}

Terdapat dua macam cara yang dilakukan oleh Masyarakat Kanekes dalam melaksanakan upacara perkawinan. Perta$\underline{\text { ma, perkawinan orang Baduy Panamping }}$ (Baduy Luar) dilakukan di depan penghulu yang berkedudukan di Kampung Cicakal Girang, dan calon pengantin harus mengucapkan syahadat Islam. Kedua, Perkawinan bagi orang Baduy Panamping, bagi mereka perkawinan dilakukan di depan Puun dan dipimpin oleh Tangkesan. Puun lah yang mengesahkan perkawinan mereka. Dam perkawinan mereka ini disebut kawin batin.

\section{Upacara Kematian}

Seseorang yang meninggal, jenazahnya dimandikan sama sebagaimana kebiasaan yang berlaku di masyarakat Sunda lainnya. Ini mirip dengan tatacara pemandian jenazah menurut Islam. Jenazah laki-laki dimandikan oleh petugas khusus diebut dukun yang berkelamin lakilaki. Sedangkan jenazah perempuan oleh dukun perempuan. Kalau dalam tradisi sehari-hari semua orang Baduy (terutama orang Baduy Tangtu) buyut memakai sabun, tetapi terhadap orang yang meninggal diperbolehkan menggunakannya. Setelah itu, jenazah di bungkus dengan kain kafan (boweh). Suatu hal yang penting dalam kaitan orang meninggal, namun tidak terdapat ditemukan pada masyarakat Baduy adalah lokasi khusus untuk tempat pemakaman. Orang yang meninggal adalah lokasi khusus untuk tempat pemakaman. Orang yang meninggal cukup dikuburkan tidak jauh dari perkampungan, yang terletak di arah utara. Dalam kehidupan sosial orang Baduy, upacara kematian hanya diperingati sampai tujuh hari saja. Mereka berpendapat, setelah tujuh hari ruh orang yang meninggal akan "pergi" menuju surga (Buana Nyungcung) untuk menghadap "penguasa atas" atau "penguasa surga" (Ambu Luhur).

\section{Upacara Nyaseuk}

Upacara menanam benih padi yang disebut Ngaseuk merupakan salah satu upacara penting pada masyarakat Kanekes. Upacara ngaseuk dimulai di "ladang suci" (huma sereng) pada bulan April atau bulan Kapitu menurut perhitungan kalender masyakat Kanekes. Ngaseuk sebenarnya membuat lubang di huma dengan menggunakan alat sejenis tongkat yang diruncingkan ujungnya, kemudian benih padi dimasukkan oleh perempuan. Upacara ngaseuk pada hakikatnya merupakan pemujaan terhadap dewi padi, Pohaci Sang Hiyang Asri. Girang serat yang memimpin upacara tersebut, membacakan jampi dan mantera-mantera tertentu dengan maksud "membangunkan" padi (ngahudangkeun) yang dianggap penjelmaan dari dewi padi. Mantera yang dibaca itu berbunyi: (A. Suhandi Shm,1986: 73)

"Tabe,

Pohaci Sang Hiyang Asri, hayu urang bakik ka weweg sampeg, 


\author{
mandala pageuh, \\ mangka tetep, \\ mangka langgeng” \\ (Hormat, \\ Pohaci Sang Hiyang Asri, \\ mari kita pulang ke tempat asalmu \\ yang kokoh, \\ yaitu mandaya yang tetap, \\ agar bisa tetap lanngeng).
}

Sebelum upacara ngaseuk itu dilaksanakan biasanya didahului dengan upacara nyacar, yakni membersihkan hutan belukar, rerumputan dan rantingranting; dan upacara nukuh, yaitu menebang pohon-pohon besar. Pada upacara nyacar dan nukuh ini mereka mempersembahkan sesaji untuk para leluhur (dangiang, dan karuhun). Pemberian sesaji ini dimaksudkan agar para dangiang tidak marah karena hutan (yang merupakan tempat tinggal para dangiang) ditebangi pepohonannya (dibukbak). Sesaji yang disiapkan dalam upacara nukuh ini dimanterai oleh Puun. Setelah dua upacara itu berlangsung, dilanjutkan pada upacara ngahuru atau ngaduruk, yakni membakar ranting-ranting atau rerumputan yang dibersihkan ketika upacara nyacar dan nukuh. Setelah semua upacara ini dilakukan, barulah berlangsung upacara ngaseuk.

Upacara-upacara yang telah diuraikan di atas, disebutkan oleh Saleh Danasasmita dan Anis Djatisunda (1986: 8, 24-36) apa yang dinamakan sebagai tugas hidup masyarakat Kanekes, yang mencakup kegiatan atau perilaku:

(1) pemeliharaan tempat pemujaan di Pada Ageung, (ngareksakeun Sasaka Pusaka Buana); (2) pemeliharaan tempat pemujaan di Parahiyangan, (ngareksakeun Sasaka Domas), yang biasanya dilakukan oleh para tokoh adat Cibeo; (3) mengasuh penguasa/pembesar, (ngasuh ratu ngajayak menak), yang lebih cenderung disebut kegiatan untuk menyampaika "hadiah", upeti kepada penguasa; (4) memper-tapakan atau mensucikan mandala Kanekes yaitu nusa 33 , sungai 65 dan pusat 25 negara yang diungkapkan dalam ungkapan (ngabaratapakeun nusa telu puluh telu, bagawan sawidak lima, pancer salawe nagara); (5) berburu dan menangkap ikan untuk keperluan upacara kawalu, yang diistilahkan dengan (kalanjakan kapundayan); (6) membakar dupa atau kemenyan pada waktu pelaksanaan suatu upacara, menyelenggarakan upacara kawalu dan membuat panganan laksa pada upacara tutup taun, (ngukus ngawalu muja ngalaksa).

\section{Upacara Kawalu dan Ngalaksa}

Kata ngawalu dan ngalaksa, pada kalimat (ngukus ngawalu muja ngalaksa) yaitu menyelenggarakan upacara Kawalu dengan membuat makanan yang disebut laksa. Kawalu dilaksanakan 3 kali dalam satu tahun, yaitu bulang Kasa disebut kawalu tembey (awal), Karo disebut kawalu tengah, dan Katiga disebut kawalu tutug (akhir). Pada bulan-bulan tersebut Masyarakat Baduy harus melakukan puasa yang disebut puasa kawalu. Puasa kawalu dilakukan hanya satu hari pada tiap bulannya, yaitu mereka melakukan puasa dengan cara tidak makan mulai tengah malan dan pada siang hari. Pada waktu menjelang malam mereka mulai makan. Demikian dilakukan pada tiap bulan Kasa, Karo, dan Katiga. Pada waktu bulan Katiga, mereka menyelenggarakan Ngalaksa, yaitu membuat makanan Laksa, sejenis makanan dari tepung beras yang dicetak atau dibuat seperti mie dan dicetak dalam tempat adonan yang disebut sangku.

Proses Ngalaksa dilaksanakan oleh ibu-ibu, padi untuk membuat laksa ini wajib dikumpulkan kepada setiap kepala keluarga. Mereka harus menyerahkan ikatan padi sejumlah anggota kekuarganya. Sebagian sumber menyebutkan, bahwa beras yang dijadikan tepung untuk membuat laksa ini harus dari tujuh rumpun padi yang ditanam di ladang suci (huma serang) yang berada di wilayah kampung Baduy Tangtu dan yang berasal dari ladang teladan (huma tuladan) kampung Baduy 
Panamping. Pada saat ngalaksa ini juga, para ketua adat, melakukan perhitungan jumlah warga, yang dilakukan dengan cara sederhana, yakni setiap kepala keluarga menyerahkan ikatan tangkai padi sesuai sesuai dengan jumlah anggota keluarganya kepada kokolot kampung setempat. Dengan demikian, perkembangan jumlah penduduk di desa kanekes dapat diketahui dengan akurat.

Setelah selesai semua ritual tersebut, masyakat Baduy bersiap untuk melaksanakan ritual Seba atay istilah yang telah dikenal yakni Upacara Seba.

\section{Upacara Seba}

Seba merupakan sebuah tradisi adat yang harus dilakukan setiap tahunnya bagi warga Baduy sebagai wujud nyata tanda kesetiaan dan dan ketaatan kepada Pemerintah RI yang dilaksanakan kepada penguasa Pemerintahan dimulai dari Bupati Lebak dan Gubernur Banten.

Seba itu sendiri dapat diartikan sebagai kunjungan resmi yang merupakan peristiwa dalam rangkaian adat masyarakat Baduy yang dilakukan seusai Kawalu dan Ngalaksa. Rangkaian acara secara terperinci serta persiapan yang matang disamping harus berpedoman pada Peraturan Adat dan orang yang berperan dalam melakukan Seba adalah kepercayaan Puun atas nama warganya memberikan laporan kepada Pemerintah sekaligus menjembatani komunikasi.

Maksud dan tujuan upacara Seba secara umum adalah untuk mengharapkan keselamatan, pernyataan rasa syukur kepada Tuhan, bahwa selama setahun masyarakat Baduy mampu mempertahankan religi dan tradisi leluhur mereka. Adapun tujuan khusus diadakan upacara Seba adalah: (1) Membawa amanat Puun; (2) Memberikan laporan selama satu tahun di daerahnya; (3) Menyampaikan harapan; (4) Menyerahkan hasil bumi; dan (5) Untuk mempererat ikatan tali silaturahmi secara formal kepada Bapak Gede.
Waktu penyelenggaraan upacara Seba telah diperhitungkan secara matang dan disepakati para jaro, warga masyarakat Baduy, baik Baduy Dalam maupun Baduy Luar, pimpinan pemerintahan mulai dari pemerintah kecamatan, kabupaten sampai ke tingkat provinsi. Tempat penyelenggaraan upacara yang termasuk dalam rangkaian upacara Seba antara lain, rute perjalanan dari Desa Kanekes ke kantor Bupati Lebak (Pendopo), dan puncaknya berakhir di kantor Gubernur Banten,

Pada umumnya, setiap upacara Seba, melibatkan Jaro Tujuh sebagai perwakilan masyarakat Baduy, Jaro Warega sebagai utusan khusus Puun, dan jaro Pamarentah (Kepala Desa Kanekes sebagau pelaksana upacara Seba). Selain itu para Dangka, Pemangku adat, tokoh masyarakat, kokolot desa, serta kaum muda (para pemuda) sebagai generasi pelanjut upacara di masa yang akan datang.

Sebelum upacara Seba dimulai, para tetua adat menyeleksi warga Baduy yang akan turut dalam pelaksanaan upacara. Pemilihan warga yang akan turut dalam Seba perlu dilakukan, mengingat pada pelaksanaanya bagi warga Baduy Kajeroan (Baduy Tangtu) akan berjalan kaki menempuh jarak yang cukup jauh dari watu berangkat dan pulang (kurang lebih $80 \mathrm{~km})$. Namun bagi warga Baduy luar (Baduy Panamping) diperbolehkan menggunakan kendaraan.

Kaum Sepuh beperan sebagai pengamat jalannya upacara dan pada saat upacara sedang berlangsung tidak berbasa basi dalam menyampaikan kata-kata, tetapi tegas, jujur, tepat dan jelas dalam menyampaikan segala permasalahan daerahnya, tidak menutupi yang buruk dan tidak memamerkan yang baik. Kelompok pemuda mempunyai kewajiban sebagai pengemban amanat pusaka untuk tidak menyimpang dari tujuan, dan kelompok Tokoh Adat mengatur tata cara yang bertumpu pada pakem, larangan dan pantangan, keharusan, sejak berangkat dari daerahnya sampai tujuan. 
Acara Seba diawali dengan pengucapan tatabean oleh Tanggungan Jaro Duabelas, yakni wakil para tetua adat Baduy. Tatabean adalah ucapan seserahan warga Baduy kepada bupati. Disebut tatabean karena diawali kata "tabe", yakni ucapan sopan santun sebelum bertutur kata. Tatabean disampaikan dalaam bahasa asli Baduy yang diwariskan turun-temurun. Diantara isinya adalah melaporkan keadaan warga Baduy. Apakah kondisi mereka sehat, panen bagus, lingkungan aman, dan sebagainya

Setelah Tanggungan Jaro Duabelas selesai menyampaikan laporan, acara dilanjutkan dengan dialog. Pada kesempatan itu, Ibu Gubernur/pak Bupati mengucapkan banyak terima kasih kepada warga Baduy. Sebab mereka telah menjaga hutan dengan sangat baik. Karena itu lingkungan hidup warga Baduy tetap terjaga.

Acara ditutup dengan penyerahan hasil bumi Baduy kepada Bupati, sebaliknya Bupati pun menyerahkan bingkisan kepada wakil warga Baduy. Acara Seba Baduy diadakan setiap tahun, yang dibawa ke kota bukan hanya hasil bumi, tetapi juga peralatan masak diantaranya Kukusan Bambu (Aseupan), Kipas Bambu (Hihid), Centong Pangarih (Sendok Aronan), alat menanak nasi yang terbuat dari kayu (Dulang).

Makna upacara Seba dibalik rangkaian ritual yang masih setia dipertahankan masyarakat Baduy adalah penegasan bahwa masyarakat Baduy merupakan masyarakat pertapa (asketis). Jika dilihat dari susunan kemasyarakatan nya. Baduy Tangtu (Baduy dalam), yaitu Cibeo, Cikertawana, dan Cikeusik, adalah merupakan tiga kampung yang paling taat menjaga adat. Letak ke tiga kampung tangtu dikelilingi oleh kampung panamping (Baduy luar). Orang panamping kedudukanya lebih rendah dibanding Banduy Tangtu menurut adat mereka. Masyarakat Baduy panamping bertugas menjaga tiga kampung tangtu dari pengaruh masyarakat luar.
Makna hasil bumi atau hasil pertanian yang mereka bawa untuk "Bapak Gede" adalah penegasan bahwa hingga saat ini masyarakat Baduy adalah masyarakat petani yang sekaligus menegaskan bahwa kehidupan mereka amat tergantung pada kondisi alam. Kondisi alam akan berpengaruh langsung dengan pertanian yang mereka usahakan. Untuk menjaga lingkungan alam agar tidak rusak, maka pada amanat Puun yang disampaikan kepada pemerintah Kaabupaten Lebak maupun Provinsi Banten yaitu agar bersama-sama dengan masyarakat Baduy agar menjaga kelestarian alam.

Ketentuan adat sangat ketat dalam menjaga dan memelihara kelestarian lingkungan mereka. Sistem perladangan berpindah (seperti telah dijelaskan di atas) sangat tergantung pada keberadaan dan kelestarian hutan di wilayah mereka. Dengan demikian hutan memegang peran penting dalam hubungan antara masyarakat Baduy dengan lingkungan alamnya.

Keberadaan mereka menurut sejarah dan kepercayaan adalah dalam rangka menjaga hutan dan mata air Sungai Ciujung yang menjadi sungai utama pada jaman Kerajaan Sunda/Pajajaran. Masyarakat Baduy diperintahkan untuk mengelola Daerah Aliran Sungai (DAS) Ciujung yang berperan sangat penting dalam bidang transportasi dan pertanian, beserta hutan yang melindungi mata airnya, yang mereka sebut sebagai Sirah Cai atau kepala air (Adimihardja, 2000). Untuk menjaga keseimbangan ekosistem hutan dan DAS tersebut, maka masyarakat Baduy yang bermukim di wilayah tersebut ditabukan untuk bercocok tanam dengan cara mengolah lahan seperti membuat petak sawah, mencangkul, atau menanami dengan tanaman untuk perdagangan.

Cara pengolahan lahan yang berlebihan dan pengusahaan lahan pertanian untuk diperdagangkan diyakini akan menimbulkan kerusakan ekosistem. Dengan demikian pertanian yang mereka praktekkan adalah pertanian sederhana, 
sesedikit mungkin mengolah tanah dan hanya untuk kebutuhan bertahan hidup secara subsisten saja. Bekas ladang akan diliarkan kembali dan menjadi hutan belukar, dan seterusnya menjadi hutan sekunder. Selain itu hewan ternak yang berkaki empat juga ditabukan mengingat injakan kaki serta kebutuhan makanan ternak akan daun-daunan dalam jumlah banyak diyakini pula dapat mengganggu kelestarian hutan.

Secara adat istiadat Baduy, hutan dibeda-bedakan berdasarkan peran dan fungsinya sebagai: hutan tua (leuweung kolot); hutan muda (leuweung ngora); semak belukar lebat bekas huma (leuweung reuma), dan semak belukar (jami). Hutan tua ada di wilayah Baduy Dalam dan jauh dari permukiman, sedangkan ketiga jenis hutan lainnya ada di sekitar perkampungan (Garna, 1993). Hutan tua di wilayah Baduy, secara adat dianggap suci dan tabu untuk dieksploitasi oleh manusia, sehingga pengawasannya ditangani oleh puun sebagai ketua adat. Hutan tua tersebut pada umumnya terletak di puncak perbukitan. Iskandar (1992, dalam Adimihardja, 2000) membagi zonasi hutan sebagaimana tertera pada gambar 2 . Zona pertama (I) yang terletak di kaki bukit biasanya diperuntukkan bagi daerah permukiman dan dukuh lembur. Zona berikutnya (II), yang semakin mengarah ke lereng diperuntukkan bagi pertanian atau huma. Sedangkan zona yang terakhir (III) yang terletak di puncak perbukitan merupakan hutan tua.

Strategi konservasi hutan secara tradisional pada masyarakat Baduy tersebut juga tercermin dalam penyusunan tata ruang, dalam hal ini susunan perkampungan penduduknya.

Perkampungan Baduy dibedakan menjadi kampung Tangtu (Baduy Dalam), Panamping (Baduy Luar), dan Dangka yang terletak diluar wilayah Kanekes. Kampung Dangka adalah kampung kecil yang merupakan kantong-kantong penyangga, atau semacam buffer zone pada lapisan terluar, berfungsi sebagai kampung penangkal bagi masuknya pengaruh luar ke wilayah Baduy. Selain itu penduduk kampung dangka juga bertugas menjaga dan memelihara hutan larangan yang terletak di luar wilayah Baduy, sebagai hutan cadangan untuk kepentingan perluasan perladangan orang Baduy (Adimihardja, 2000). Namun demikian, keberadaan hutan larangan di wilayah dangka tersebut semakin lama semakin sempit, karena berbagai penyerobotan, penjarahan, dan penggundulan yang dilakukan secara terus menerus oleh masyarakat di sekitar. Bahkan sejak jaman Belanda, banyak bagian dari hutan larangan di wilayah Dangka tersebut yang diubah menjadi perkebunan karet. Dengan demikian fungsi Kampung Dangka sebagai buffer zone tersebut semakin lama semakin tidak berarti. Menurunnya fungsi dan peranan Kampung Dangka tersebut tercermin pula dari penurunan jumlah kampung yang ada. Pada awalnya terdapat 9 Kampung Dangka (Adimihardja, 2000). Pada 1929 jumlah kampung dangka telah menyusut menjadi 7 kampung, dan selanjutnya pada 1975 sampai dengan tahun 2000 hanya tinggal 3 kampung dangka lagi (Makmur, 2001). Sedangkan pada saat penelitian ini dilakukan pada tahun 2003, hanya tersisa 2 kampung dangka saja. Dengan menyusutnya jumlah kampung dangka maka warga Baduy yang tinggal di kampung dangka kemudian ditarik ke wilayah Kanekes.

Dengan pola yang ada maka ekosistem Baduy tidak bersifat berkelanjutan kecuali terjadi perubahan dan adaptasi dari sistem sosial mereka. Mengingat adat istiadat yang bersifat 'bertahan dari segala perubahan' atau sedapat mungkin menolak perubahan maka keadaan tersebut menjadi kritis bagi eksistensi Baduy.

\section{PENUTUP}

Manusia dalam hidupnya senantiasa dan pasti dituntut menyesuaikan diri dengan tatanan masyarakatnya dan lingkungannya. Tidak ada suatu mahluk pun di 
dunia ini yang dapat hidup tanpa melibatkan manusia lain, baik itu benda mati maupun mahluk hidup. Untuk mempertahankan kehidupan, setiap manusia akan berhubungan dengan sesamanya yang di dalamnya terdapat seperangkat tata aturan, hukum, norma-norma, dan nilai-nilai yang berlaku dan diakui oleh masyarakatnya. Upaya inipun dalam rangka hidup harmonis dan berlangsung terus menerus. Manusia seperti ini yang disebut manusia berbudaya.

Religi atau kepercayaan masyarakat merupakan salah satu unsur kebudayaan (dari tujuh unsur kebudayaan yang bersifat universal) yang berkaitan erat dengan emosi keagamaan. Sebagaimana dimaksudkan dalam tulisan ini bahwa religi atau kepercayaan masyarakat Baduy yaitu yang disebut Sunda Wiwitan, merupakan religi yang menggambarkan konsep ketakwaan kepada Tuhan Yang Maha esa pada masyarakat Desa Kanekes. Di dalamnya mengandung serangkaian aturan, pengetahuan dan petunjuk untuk dilaksanakan para waga masyarakatnya. Pelaksanaah dari konsep religi Sunda Wiwitan yang tersusun dalam konsep pikukuh, pada dasarnya merupakan peneguh adat dan penyaring pengaruh-pengaruh dari luar. Sistem kepercayaan itu akhirnya menjadi rangkaian pengetahuan masyarakat Baduy yang berperan dalam mengatur hubungan timbal balik antara manusia dengan manusia, manusia dengan alam, maupun hubungan manusia dengan penciptanya.

Rangkaian upacara, mulai dari upacara Kawalu dang Ngalaksa dan ditutup dengan upacara Seba, bagi masyatakat Kanekes, merupakan sistem nilai yang berfungsi sebagai patokan perilaku atau tata kelakuan dalam hidup. Semuanya itu diwariskan kepada warga masyarakat Desa Kanekes dari nenek moyang mereka, karena itu harus dipatuhi dan dilaksanakan.

Upacara Seba yang dilakukan oleh masyarakat Baduy merupakan refleksi dari kearifan lokal (local wisdom) mereka. Upacara Seba merupakan bentuk kegiatan adat yang sangat penting bagi masyarakat Baduy, karena bukan hanya upacara adat yang melibatkan masyarakat Baduy itu sendiri, tetapi juga melibatkan masyarakat luas yakni pemerintah daerah setempat. Selain itu, Seba dianggap sebagai upacara penutup daru serangkaian upacara adat sebelumnya. Upacara ini menjadi sangat "unik", karena mereka mendatangi penggede atau pemerintahan kabupaten dan pemerintah provinsi. Dengan rombongan yang begitu besar, upacara ini sangat menarik bukan hanya masyarakat yang dilalui rombongan masyarakat Baduy untuk menuju tenpat upacara Seba, tetapi juga menarik masyarakat di luar wilayah kabupaten Lebak dan Provinsi Banten.

Upacara Seba bagi masyarakat Baduy merupakan media silaturahmi antara mereka dengan pemangku pemerintahan formal, yakni pemerintah Kabupaten Lebak dan Pemerintah Provinsi Banten. Silaturahmi ini merupakan wujud keterikatan antara masyarakat Baduy dengan pemerintah, yang keduanya saling membutuhkan.

Secara umum makna simbol dari pelaksanaan upacara Seba adalah keberhasilan masyarakat Baduy dalam menjalankan kehidupan sehari-hari, terutama berkah yang diberikan Tuhan Yang Maha Kuasa atas keberhasilan panen yang telah mereka lakukan. Oleh karena itu, simbol keberhasilan panen juga dibawa dalam upacara Seba, seperti beras, ubi-ubian, dan hasik panen lainnya. Seba juah mengandung makna ketaatan atau kepasrahan angota masyarakat, khususnya Baduy, terhadap pemerintah yang berwenang.

Upacara Seba yang dilaksanakan masyarakat Baduy mempunyai makna kemasyarakatan. Hal ini dapat dipahami bahwa upacara Seba dimaksudkan untuk menjalin silaturahmi antara masyarakat Baduy dengan pemerintah kabupaten dan provinsi sehingga terjalin komunikasi dua arah. Selain itu, dengan upacara Seba bagi masyarakat Baduy sekaligus mengakarabkan seluruh anggota masyarakat dalam 
menjalani kegiatan yang sama, yakni upacara Seba.

Upacara Seba juga merupakan tradisi yang ada di masyarakat Indonesia, sehingga secara sosial budaya memang perlu dilestarikan dan dipertahankan sebagai aset bangsa Indonesia. Oleh karenanya, bukan untuk dieksploitasi sebagai sumber daya, namun lebih menjadi modal sosial bagi masyarakat Baduy, masyarakat Banten, dan masyarakat Indonesia pada umumnya.

Upacara Seba menunjukka sikap hidup harmoni, masyarakat Baduy tidak mengenal konflik di antara mereka. Mereka saling menghargai dan menghormati, bukan hanya di antara mereka tetapi terhadap semua orang dan bahkan menghormati lingkungan mereka. Masalah apapun yang dihadapi anggota masyarakat dapat diselesaikannya. Saling menghargai, menghormati dan memahami di antara anggota masyarakat Baduy sampai sekarang masih dipegang teguh, sehingga kehidupan harmoni mereka sampai sekarang masih dapat diwujudkan. Peran Puun sangat menentukan, sehingga tidak ada anggota masyarakat yang tidak menyetujui. banyak falsafah hidup mereka yang sanagat baik, yakni mentaati semua adat yang berlaku tanpa perkecualian atau mengurangi dan menambah.

Kebudayaan masyarakat Kanekes yang masih asli jika dilihat dalam konteks pergaulan jaman sekarang, adalah hasil upaya mereka yang dengan gigihnya menjaga supaya tidak hanyut oleh derasnya arus komunikasi. Oleh karena itu, kepada berbagai pihak baik pemerintah maupun masyarakat luas, agar menghormati pilihan hidup mereka. Berupaya memandang mereka sebagaimana layaknya manusia yang normal, karena memang sejatinya mereka adalah manusia yang normal dan mandiri. Dengan cara pandang seperti ini, maka akan menghasilkan suatu pergaulan yang sehat bersama mereka.

\section{DAFTAR SUMBER}

\section{Buku}

Adimihardja, K. (2000).

Orang Baduy di Banten Selatan: Manusia air pemelihara sungai, Jurnal Antropologi Indonesia, Th. XXIV, No. 61, Jan-Apr 2000, hal 47-59.

Danasasmita, Saleh et. al. 1986.

Kehidupan Masyarakat Kanekes, Bandung: Bagiab Proyek Penelitian dan Pengkajian Kebudayaan Sunda (Sundanologi). Direktorat Jenderal Kebudayaan Departemen Pendidikan Dan Kebudayaan.

Djoewisno M.S., 1984.

Potret Kehidupan Masyarakat

Baduy. Banten

Harsoyo, 1982.

Pengantar Antropologi. Cet.

IV.Jakarta: Binacipta.

Iskandar, Johan. 1992.

Sistem Perladangan Pada masyarakat Baduy. Bandung: Jembatan.

Koentjaraningrat, 1980.

Beberapa Pokok Antropologi Sosial, Jakarta: Dian Rakyat.

1982.

Kebudayaan Mentalitet Dan Pembangunan. Cet. IX Jakarta: Gramedia.

1993.

Masyarakat Terasing di Indonesia, Jakarta: PT. Gramedia.

Singarimbun, Masri et. al. 1985.

Metode Penelitian Survei, Cet. V. Jakarta: LP3ES.

Soeriadiradja, R. Djatnika., 1951.

Baduy: Buku Bacaan Bahasa Sunda.

Kementrian Pendidikan Pengajaran

Dan Kebudayaan. Jakarta. 
Suhada, 2003.

Masyarakat Baduy Dalam Rentang Sejarah. Banten: Dinas Pendidikan Provinsi Banten.

Suhandi, A. Shm. (et. all), 1986.

Tata Kehidupan Masyarakat Baduy di Provinsi Jawa Barat. Bandung: Proyek Inventarisasi dan Dokumentasi Kebudayaan Daerah. Departemen Pendidikan Dan Kebudayaan.

2. Makalah, Brosur, Surat Kabar, dll.

Anis Djatisunda, 2005.

Sunda Wiwitan Agama Orang Sunda Yang Berpribadi Sunda. Makalah dalam sebuah seminar bertema: Memahami Sunda Wiwitan dalam Konteks Kebudayaan Sunda. Bandung.

Asghary, Basri Iba. 1988.

Semalam di Kampung Tangtu Cibeo Bersama Orang Baduy Dalam. Majalah Amanah. Jakarta, Nopember.

Edwin, Norman,. 1980.

Arca Domas dan Badui di Kanekes. Dalam Intisari no. 202, Jakarta: Gramedia, Mei. Hal. 120 - 128.

Purwitasari, Tiwi., 2000.

Kultus Arca Domas dan Pelestarian Hutan: Studi Kasus Komunitas Baduy. Kompol-Jawa Barat. Dalam Etty Saringendyati (ed.). Kronik Arkeologi: Perspektif Hasil Penelitian Arkeologi di Jawaq Barat, Kalimantan Barat dan Lampung. Jakarta: Pusat Arkeologi Nasional. Hal. 64-73.

Subagiyo Kodrat, 1975.

Sekelumit Tentang Masyarakat Kanekes (Masyarakat Baduy) Di Kabupaten Lebak. Rangkasbitung: tp. Thn. 